\title{
INFORMATION TOOLS FOR CULTURAL TOURISM DESTINATIONS: MANAGING ACCESSIBILITY
}

\author{
Ivor Ambrose \\ Katerina Papamichail
}

https://doi.org//10.20867/tosee.06.2

\begin{abstract}
Purpose - This paper is prepared in connection with the H2020 IMPACTOUR project on "Improving Sustainable Development Policies and Practices to access, diversify and foster Cultural Tourism (CT) in European regions and areas". It addresses the development of indicators for the management of accessibility in European CT destinations, responding to the growing accessible tourism market as a driver of sustainable tourism strategies.

Methodology - The paper describes the development of tools, indicators and metrics for gathering accessibility information, which DMOs may use as part of the IMPACTOUR CT destination management system. It reports on global and European destination management systems and tools, and describes key requirements for accessibility indicators, namely: 1) Validity, 2) Reliability, 3) Universality, 4) Availability, 5) Scalability and 6) Operability.

Findings - A set of "core indicators" and additional "optional indicators" are selected for initial testing in the IMPACTOUR Destination Pilot Sites in various EU countries. Pilot destinations and representative groups of citizens and visitors will be engaged in testing and validating the accessibility parameters of the tool and demonstrating how tourists with access requirements can be suitably catered for within the overall framework of sustainable destination management. Contribution - The paper describes the development of information tools supporting CT destinations in managing the demands of the growing accessible tourism market. The use of accessibility indicators in destination management is part of the holistic, data-driven approach promoted by IMPACTOUR, aiming to ensure inclusive cultural tourism for all visitors and citizens in the host communities.
\end{abstract}

Keywords: Cultural Tourism, Destination Management, Accessibility, Indicators.

\section{INTRODUCTION}

The European Commission (EC) has noted that cultural tourism accounts for $40 \%$ of all European tourism and 4 out of 10 tourists choose their destination based on its cultural offering. Cultural Tourism includes natural heritage sites and parks, museums, theatres, archaeological sites, historical cities, industrial sites as well as music and gastronomy. (EC 2021).

The European Commission also estimates that by 2020, about one-fifth of all persons in Europe live with a disability. For the tourism sector this represents both a challenge, in terms of creating suitable accessible environments and services but also a golden opportunity by attracting and serving customers with access requirements, their families and friends. In addition to persons with disabilities there are also many other travellers who must take into account their specific access requirements when travelling, such as 
ToSEE - Tourism in Southern and Eastern Europe, Vol. 6, pp. 25-37, 2021.

I. Ambrose, K. Papamichail: INFORMATION TOOLS FOR CULTURAL TOURISM DESTINATIONS...

persons with long-term health conditions, families with small children, those with dietary restrictions, persons with allergies, and those who may have a temporary impairment due to an accident or perhaps recovery from illness or a medical procedure (Ambrose 2021).

For these individuals, accurate, up-to-date and detailed accessibility information is essential, as they are likely to need certain environmental conditions, equipment, services or other supports that enable them to function safely, comfortably and - as far as possible - on equal terms with other customers. Without the provision of accessibility measures both on the journey and at the venue, these groups are restricted in their choice of where they can travel and what they can do. Accessibility information, provided by the tourism supplier or destination management organisation is critical to the visitor journey, from its very inception, through the entire journey and until the tourist returns home (Buhalis and Michopoulou 2011, 2013), (Michopoulou, Darcy, Ambrose and Buhalis 2015).

In an EU-funded study, the accessible tourism market in Europe, has been estimated at 138.6 million persons, comprising persons with disabilities aged 15 to 64 (35.9\%) and those over the age of 65 , who have a high incidence of age-related impairments and health conditions (64.1\%), (European Commission 2015). This is a large and growing market, accounting for about 1 in every 5 travellers, due to the ageing of the populations, both in European countries and in many "feeder" markets. Catering to the accessibility requirements of customers is seen as a competitive advantage, providing a pathway to higher levels of service for all customers. In addition, businesses that address this market can gain in terms of reputation by demonstrating corporate social responsibility (CSR). As stated by Veitch (2017):

“Addressing all aspects of accessibility, where visitors' different needs are both understood and anticipated through the delivery of relevant information, supported by trained staff and the provision of appropriate facilities, will ultimately benefit all your visitors. Accessible Tourism is relevant for everybody, not just the obvious groups of disabled and older people who have access requirements. Many may travel independently, many will travel in groups, with family and friends for leisure or as part of their business, attending meetings and conferences. Understanding and responding to their access requirements means business can be won, ignoring them means business can be lost to the competition."

Europe is the largest global tourism market, attracting $40 \%$ of tourists by volume (before the COVID-19, in early 2020). Global organisations such as the UN World Tourism Organisation have made considerable efforts to draw attention to the need for accessible in tourism, emphasising the need for States Parties to develop their tourism industry and destinations in line with the requirements of the UN Convention on the Rights of Persons with Disabilities (United Nations 2006). Article 30 of the Convention, addresses "Participation in cultural life, recreation, leisure and sport", and requires, inter alia: "...appropriate measures to ensure that persons with disabilities:

a) Enjoy access to cultural materials in accessible formats;

b) Enjoy access to television programmes, films, theatre and other cultural activities, in accessible formats; 
ToSEE - Tourism in Southern and Eastern Europe, Vol. 6, pp. 25-37, 2021.

I. Ambrose, K. Papamichail: INFORMATION TOOLS FOR CULTURAL TOURISM DESTINATIONS...

c) Enjoy access to places for cultural performances or services, such as theatres, museums, cinemas, libraries and tourism services, and, as far as possible, enjoy access to monuments and sites of national cultural importance." [Continues].

The European Union and all EU Member States have signed and ratified the UNCRPD, making this and all other articles binding and subject to national and international laws.

The UN World Tourism Organisation dedicated the World Tourism Day 2016 to the subject of Accessible Tourism, with the highlight of the year being the international Congress on Accessible Tourism held in Bangkok, Thailand, emphasising the importance of this growing market and the role of the UNWTO in supporting "sustainable and universally accessible tourism for all".

Accessibility is highlighted in tourism policy documents such as the UNWTO Kyoto Declaration on Tourism and Culture (2019), which expresses the need to redefine tourism management to advance local community participation in responsible tourism by inter alia:

"(1.4) Developing policies to mitigate the negative impacts of tourism growth on the use of cultural and natural resources, in particular properties inscribed on the UNESCO World Heritage list, and applying strategic destination management systems that promote the seasonal, regional and time-based dispersal of visitors in response to growing concerns and pressures related to "overtourism";

(1.5.) Reinforcing ethical principles in the tourism sector through the implementation of the UNWTO Global Code of Ethics for Tourism and adopting related policies, codes of conduct and governance systems;

(3.1) Establishing management systems that combine up-to-date knowledge, digital solutions and inclusive approaches to enhance the visitor experience as well as respect for communities' needs, adequate interpretation and fair trade.

(3.2) Building measurement systems that create an enabling environment for cultural investments to thrive while tracking the added value of culture, visitor flows and the distribution of benefits..."

(UNWTO 2019)

Against this global and European background, the IMPACTOUR project was designed, with the participation of ENAT, the European Network for Accessible Tourism, to contribute its knowledge to the design of the CT destination management tool. DMOs should then benefit from creating accessible tourism venues and services which meeting the required standards and improve their revenue streams by attracting a more diverse range of visitors and locals to their cultural offers.

\section{METODOLOGY}

In the current (first) phase of the IMPACTOUR project, four domains are considered: Social Impacts, Cultural Impacts, Environmental Impacts and Economic Impacts. This paper addresses the subject of accessibility for persons with disabilities and other visitors 
ToSEE - Tourism in Southern and Eastern Europe, Vol. 6, pp. 25-37, 2021.

I. Ambrose, K. Papamichail: INFORMATION TOOLS FOR CULTURAL TOURISM DESTINATIONS...

with specific access requirements, as one of the significant cross-cutting factors in CT destination management and service design, that impacts on all four domains, for moral, financial and legal reasons. The paper identifies the main tools, performance indicators, metrics and standards on accessibility that have been developed in recent years at regional, national, European and global levels. This is followed by a critical assessment of the current state of the art, based on "best practices" in accessible tourism that point to those indicators and methods that can support the development of the intended IMPACTOUR CT destination management tool. The paper contributes to knowledge on the design of accessibility information and indicators for CT destination management, aiming to ensure socially inclusive and sustainable cultural tourism for all visitors and citizens in the host communities. The implementation of accessibility information and support measures in relation to customers' safety, comfort and satisfaction are seen as important features in the tourism sector's efforts to "build back better" following the impact of the global COVID-19 pandemic.

To determine the most appropriate indicators for accessible tourism in cultural tourism destinations, the investigators reviewed a range of information and management systems and documents currently in use (or soon to be available) in Europe. These included:

- $\quad$ ETIS - the European Tourism Indicators System for sustainable tourism destinations (European Commission, 2016

- Global Sustainable Tourism Council (GSTC) Destination Criteria (2019)

- Guidance documents on "Accessible Tourism Indicators" for tourism authorities and DMOs, prepared by ENAT and ONCE Foundation for the UN World Tourism Organisation (UNWTO 2015)

- ISO Standard FDIS/21902 Accessible Tourism Services.

Both ETIS and GSTC are intended to support the management of sustainable tourism destinations, each placing some emphasis on accessibility within their own frameworks and rationale. Each or them places cultural tourism and accessibility indicators under separate headings, which could be contested to some extent. The UNWTO Accessible Tourism Indicators, on the other hand are entirely focused on accessibility, covering a very wide range of issues, as will be seen, below.

In addition, several so-called “Accessibility Information Schemes" (AIS) were reviewed in order to assess their usefulness for destination-level characterisation and for visitor impact management. AIS are sources of information that aim to assure the quality of tangible assets and tourism services provided at tourist destinations. Typically, AIS may be managed by public or private enterprises or NGOs; they intend to fulfil the need for accessibility information by tourists with disabilities or persons with other access requirements. AIS are increasingly used by cities, destinations, CT sites and accommodation providers for providing access information to potential visitors as means of marketing their offers, aiming to attract more visitors with access requirements.

In the initial phase of the desk research to identify key destination indicators, conducted by the IMPACTOUR partner, Tecnalia, the so-called "RACER principles" were used to obtain "Relevant, Acceptable, Credible, Easy and Robust" sets of indicators. 
ToSEE - Tourism in Southern and Eastern Europe, Vol. 6, pp. 25-37, 2021.

I. Ambrose, K. Papamichail: INFORMATION TOOLS FOR CULTURAL TOURISM DESTINATIONS...

For the proposed accessibility indicators, we have added to the RACER scheme a more specific set of requirements, as follows:

1) Validity - indicators reflect the actual state of accessibility in a manner which is objectively measured or described and relates to the access requirements of users (visitors) with specific functional impairments or conditions;

2) Reliability - indicators provide accurate and reproducible measures of accessibility, independent of the person who makes the assessment, or measurement (i.e. objectively measured using standardised assessment tools and methods;

3) Universality - the combined set of indicators provide appropriate assessments covering the access requirements for persons with a range of mobility, sensory, hearing, visual and cognitive impairments/neurodiversity,

4) Availability - indicators should be obtainable in the form of objective data or information, that is displayed/published by the DMO and/or its partners and stakeholder organisations or from publicly available sources such as national, regional or local (e.g. city) tourism information websites. Accessibility information should be gathered with suitable frequency and dependability to allow periodic and timely reporting and should be provided with a publication date;

5) Scalability - indicators should be applicable to destinations of different geographical sizes and visitor/population sizes;

6) Operability - indicators provide clear evidence for the development of action plans or actions for management and improvement of accessibility in cultural tourism destinations.

It should be mentioned that the proposed accessibility indicators derived from published systems, shown below, are intended as an intermediate output of the IMPACTOUR project, which will feed into a refined and much larger overall set of indicators covering all relevant aspects that are required for the CT destination management tool. In later phases of the work the accessibility indicators must be further tested, in particular in relation to their actual availability in destinations. Those DMOs that do not already participate in an AIS, for example, may be unable to respond to most if not all the accessibility indicators.

\section{FINDINGS}

Accessibility indicators in current tourism destination management and information systems

Here we briefly review a number of internationally applied destination indicators systems with regard to the prevalence of criteria and indicators for accessibility.

The European Tourism Indicator System (ETIS)

ETIS (2016), was developed over several years through expert advice, stakeholder consultation and field-testing in about 100 destinations. It is described by the EU Commission as follows: 
ToSEE - Tourism in Southern and Eastern Europe, Vol. 6, pp. 25-37, 2021.

I. Ambrose, K. Papamichail: INFORMATION TOOLS FOR CULTURAL TOURISM DESTINATIONS...

"The system is specifically intended for tourism destinations. It is designed as a locally owned and led process for monitoring, managing, and enhancing the sustainability of a tourism destination. It has been developed as a result of lessons learned from previously existing indicator system initiatives and fine-tuned as a result of feedback collected from field testing, in a number of different destinations in Europe. The system is made up of a set of Indicators, a toolkit, and a dataset. [...] It can be a useful way to track destination performance and make better management decisions, as well as influence adequate policies. The 43 core indicators cover the fundamental aspects of sustainability monitoring and provide the basis for effective destination management. They also allow for comparison over time and for benchmarking between destinations.

\section{"Supplementary indicators}

Once a clear process has been established for monitoring the core indicators, destinations may wish to collect additional information that is tailored more to their destination type or category or the particular tourism market that they serve or promote.

The ETIS therefore includes the opportunity to consider supplementary indicators that add to the basic information provided and allow destinations to tailor the system to their own particular needs or destination category, e.g. mountain, city, rural, coastal, island and urban areas, as well as coordinated approaches and macroregional and/or transnational dimensions."

(European Commission, ETIS 2016)

Table 1 presents the 4 ETIS indicators that were selected to measure a destination's performance in relation to accessibility/inclusion criteria.

Table 1: ETIS Criteria and Indicators related to accessibility or inclusion

\begin{tabular}{lcl}
\hline Criteria & $\begin{array}{c}\text { Indicator Reference } \\
\text { Number }\end{array}$ & \multicolumn{1}{c}{ ETIS Core Indicators } \\
\hline $\begin{array}{l}\text { C.4 Inclusion/ } \\
\text { accessibility }\end{array}$ & C4.1 & $\begin{array}{l}\text { Percentage of rooms in commercial } \\
\text { accommodation establishments accessible for } \\
\text { people with disabilities }\end{array}$ \\
& Percentage of commercial accommodation \\
establishments participating in recognised \\
accessibility information schemes \\
C4.3 & $\begin{array}{l}\text { Percentage of public transport that is accessible to } \\
\text { people with disabilities and specific access } \\
\text { requirements. } \\
\text { Percentage of tourist attractions that are accessible } \\
\text { to people with disabilities and/or participating in } \\
\text { recognised accessibility information schemes }\end{array}$ \\
\hline
\end{tabular}

The indicators listed above represent a reduced list of indicators as compared to the list that was proposed by the European Network for Accessible Tourism (ENAT) during the ETIS stakeholder consultations, well before the final core indicators were selected. Notably, numbers $4.1,4.3$ and 4.4 make specific reference to accessibility to (or for) "people with disabilities", while 4.2 and 4.4. refer to "participating in recognised 
ToSEE - Tourism in Southern and Eastern Europe, Vol. 6, pp. 25-37, 2021.

I. Ambrose, K. Papamichail: INFORMATION TOOLS FOR CULTURAL TOURISM DESTINATIONS...

accessibility information schemes". This variation in wording reflects the fact that many (indeed most) destinations in European Member States do not participate in local, regional, European or international Accessibility Information Schemes (AIS), which entails that many DMOs will be unlikely to give a valid response to some of these items.

Only 4.4 refers to "tourist attractions" which may or may not be considered "cultural tourism venues". For our purposes, we would recommend that all venues, that is, including all types of CT venues should participate in a recognised AIS.

Notably, the use of the term "recognised AIS" in the ETIS indicators table implies that a certain authority is responsible for such a scheme. However, as pointed out above, the relevant body which offers accessibility information may be a public, private or third sector organisation, depending on the country or region concerned. The legal status of the AIS should preferably be indicated at the point of publication of access information and, where possible, the accessibility reference or standards that are applied should also be cited, along with other information concerning the scheme. Ideally, AIS assessments should be carried out by trained, $3^{\text {rd }}$ party assessors, using industry-standard methods.

Given the nature of the ETIS indicators, these would provide only a "high-level" picture of destination's accessibility, mainly in terms of the governance or management of accessibility at the site. It would be up to the DMO to develop an accessibility data-set capable of giving a finer resolution for different classes of tourism venues and services. This is where IMPACTOUR and ENAT can possibly assist with further tools for assessment and aggregation of accessibility data.

The EU Commission Report: "Study on the feasibility of a European tourism indicator system for sustainable management at destination level" (2019) is introduced with the following statement:

"[However,] there is currently no widely accepted process and methodology for the sustainable management of destinations using the [ETIS] indicators. The European Commission aims to address this and move towards more comprehensive, inclusive and sustainable ways of working, by providing an indicator system for destinations to use on a voluntary basis. This will ultimately improve the information available to tourism stakeholders and add value to the European tourism experience. The long term aim is that the system will serve as a guide to policy makers and other destination stakeholders for the improved management of tourism destinations across Europe. The task of the project team was to develop an inclusive, user-friendly methodology for applying indicators to enhance the sustainable management of tourism destinations across Europe."

The 2019 Study made some general recommendations, including this one, that is particularly relevant to the development of IMPACTOUR indicators:

"State the rationale for including each indicator in the toolkit and address "applicability" or "appropriateness" of some of the indicators, e.g. accessibility issues"

(European Commission 2019, 5). 
ToSEE - Tourism in Southern and Eastern Europe, Vol. 6, pp. 25-37, 2021.

I. Ambrose, K. Papamichail: INFORMATION TOOLS FOR CULTURAL TOURISM DESTINATIONS...

Unfortunately, this report only provides an overview and does not explain the above recommendation in greater detail, nor does it give any suggestion as to why the accessibility issues are singled out. This subject will be raised with the authors of the ETIS report to clarify what is meant by this recommendation.

\section{The Global Sustainable Tourism Council (GSTC)}

GSTC (2019), was consulted to identify possible criteria for measuring accessibility of destinations. In their second version updated set of Destination Criteria, GSTC writes:

"[The criteria] reflect certification standards, indicators, criteria, and best practices from different cultural and geo-political contexts around the world in tourism and other sectors where applicable. Potential indicators were screened for relevance and practicality, as well as their applicability to a broad range of destination types. They were field-tested around the world. The GSTC Destination Criteria v2.0 is the first revision to GSTC Destination Criteria. The GSTC-D v2 includes performance indicators designed to provide guidance in measuring compliance with the Criteria. Application of the criteria will help a destination to contribute towards the 2030 Agenda for Sustainable Development and the 17 Sustainable Development Goals. Against each of the Criteria, one or more of the 17 SDGs is identified, to which it most closely relates."

With respect to accessibility, GSTC (Destinations) identifies the following criteria and indicators, together with the reference to the relevant UN Sustainable Development Goals.

Table 2: GSTC Destination Criteria and Indicators related to accessibility

\begin{tabular}{|c|c|c|}
\hline Criteria & Indicators & SDGs reference \\
\hline $\begin{array}{l}\text { B8 Access for all } \\
\text { Where practical, sites, facilities and } \\
\text { services, including those of natural } \\
\text { and cultural importance, are } \\
\text { accessible to all, including persons } \\
\text { with disabilities and others who } \\
\text { have specific access requirements } \\
\text { or other special needs. Where sites } \\
\text { and facilities are not immediately } \\
\text { accessible, access is afforded } \\
\text { through the design and } \\
\text { implementation of solutions that } \\
\text { take into account both the integrity } \\
\text { of the site and such reasonable } \\
\text { accommodations for persons with } \\
\text { access requirements as can be } \\
\text { achieved. Information is made } \\
\text { available on the accessibility of } \\
\text { sites, facilities and services }\end{array}$ & $\begin{array}{l}\text { a. The existence of any } \\
\text { regulations and standards } \\
\text { regarding the accessibility of } \\
\text { visitor sites, facilities and } \\
\text { services. } \\
\text { b. Consistent application of } \\
\text { accessibility standards in public } \\
\text { facilities. } \\
\text { c. Data on the extent/proportion } \\
\text { of visitor sites and facilities that } \\
\text { are accessible. } \\
\text { d. Evidence of programmes to } \\
\text { improve access for people with a } \\
\text { range of access needs. } \\
\text { e. Information on accessibility } \\
\text { included in communications } \\
\text { about the destination as a whole. } \\
\text { f. Details of accessibility included } \\
\text { in visitor information about key } \\
\text { sites. }\end{array}$ & $\begin{array}{l}\text { 3. Good health } \\
\text { and wellbeing } \\
10 \text { Reduced } \\
\text { inequalities }\end{array}$ \\
\hline
\end{tabular}


ToSEE - Tourism in Southern and Eastern Europe, Vol. 6, pp. 25-37, 2021.

I. Ambrose, K. Papamichail: INFORMATION TOOLS FOR CULTURAL TOURISM DESTINATIONS...

The GSTC approach to indicator-setting gives a clear statement of the criteria against which the destination management is measured. GSTC sets goals for the general governance or management of accessibility, aiming for maximal access to all tourist sites for persons with disabilities and others with "special needs". [Note: ENAT rejects the term "special needs" in this context and prefers to use "specific access requirements", which is more accurate and is also preferred by disability advocacy groups as less patronising].

GSTC also introduces the concept of "reasonable adjustment", emphasising that where full access is not available, alternative means of enjoying the experience should be offered where possible.

GSTC applies six indicators which cover the applicable access standards at the destination, the extent of compliance with standards, existence of access programmes, accessibility information to be included in general information about the destination as a whole and provision of accessibility information in information about key sites.

Notably, GSTC - like ETIS - is only concerned with "supply-side" indicators of accessibility. Neither scheme has any indicators relating to visitor demand, such as \% of visitors who have disabilities, $\%$ of visitors who request some form of assistance service or $\%$ of enquiries that relate to accessibility issues.

UNWTO Manual on Indicators for Assessing Accessibility in Tourism. Module IV: Indicators for Assessing Accessibility in Tourism (2015) - in Spanish only.

The UNWTO indicators manual, prepared with the assistance of ONCE Foundation and ENAT, is a comprehensive document of 87 pages, providing both criteria and measurement parameters on all aspects of tourism service provision and visitor feedback. It draws on international expertise in accessible tourism, standards in tourism and accessibility and the input of disabled peoples' organisations. It covers all aspects of the visitor experience, the management of venues of various kinds and issues concerning governance, accessibility planning and also education and training.

A detailed examination of this material, with a view to informing the IMPACTOUR project will form part of the future work of the ENAT team.

ISO Standard on Accessible Tourism (ISO 21902:2021)

Here, we make a short reference to the first international standard on accessibility in tourism. It contains a section on Accessibility Management Systems which is relevant to CT destinations and, indeed destinations and businesses of all kinds.

This new ISO Standard emphasises the need for awareness-raising, training of management and staff and the importance of inclusion of accessibility criteria in infrastructure, products and services. There should also be framework for continuous 
ToSEE - Tourism in Southern and Eastern Europe, Vol. 6, pp. 25-37, 2021.

I. Ambrose, K. Papamichail: INFORMATION TOOLS FOR CULTURAL TOURISM DESTINATIONS...

improvement of the quality of the tourist experience, adopting a Universal Design approach.

While it does not give indicators for accessibility, as such, the ISO standard gives requirements and recommendations for the criteria to be set by destinations, covering built environment, tourist information, promotion, communication and customer service. Indicators should be used to allow for verification that access plans are being fulfilled. In addition, internal audits on application of legislation and standards and the conformity with general internal management protocols are recommended. Finally, surveys of customer satisfaction complaints procedures should be in place to gather data form customers and improve both policies and services.

\section{Accessibility Information Systems (AIS) - Pantou Accessibility Tourism Directory}

Over 40 AIS were examined, drawn from a global listing maintained by ENAT at: https://pantou.org/accessibility-info - The Accessible Tourism Directory. It should be noted that the Pantou Directory is not an AIS, but "signposts" readers to accessible tourism service providers that are assessed for accessibility and who publish their accessibility information at their own website or through an AIS. Given that over 100 AIS have been developed over, approximately, the last 15 years (and many have also failed and disappeared), those listed in the Pantou Directory are considered as the most reliable and current. From the analysis of the AIS that are referenced in the Pantou Directory, we can highlight the following, shown in Table 3, as being particularly worthy of examination for identification of possible accessibility indicators for CT destinations, on account of their scope, longevity, dependability and their widespread use by both the tourism sector and tourists with access requirements.

Table 3: Selected Accessibility Information Schemes from Pantou.org Accessible Tourism Directory

\begin{tabular}{lcc}
\hline Name & Geographical scope & \multicolumn{1}{c}{ Link } \\
\hline $\begin{array}{l}\text { Toegankelijk } \\
\text { Vlaanderen }\end{array}$ & Belgium & $\begin{array}{l}\text { https://toevla.vlaanderen.be/publiek/nl/re } \\
\text { gister/start } \\
\text { Reisen für Alle } \\
\begin{array}{l}\text { Agencia Catalana } \\
\text { de Turisme }\end{array}\end{array}$ \\
$\begin{array}{l}\text { BarcelonaTurisme } \\
\text { Sudtirol (Italien) }\end{array}$ & http://www.reisen-fuer-alle.de/ \\
$\begin{array}{l}\text { TUR4all (Spain } \\
\text { and Portugal) }\end{array}$ & Spain & http://turismeperatothom.catalunya.com/ \\
\hline
\end{tabular}

From the review of the above internal indicator systems and AIS, a set of "core indicators" and additional "optional indicators" are to be selected for initial testing in the IMPACTOUR Destination Pilot Sites in various EU countries. The project partners will apply these accessibility indicators as part of the development path of the IMPACTOUR CT management tool in the next phase of the project. This will involve close collaboration with more than 20 "Pilot CT destinations" and representative groups of 
ToSEE - Tourism in Southern and Eastern Europe, Vol. 6, pp. 25-37, 2021.

I. Ambrose, K. Papamichail: INFORMATION TOOLS FOR CULTURAL TOURISM DESTINATIONS...

citizens and visitors, who will test and validate the accessibility parameters of the tool. The final selection of indicators will demonstrate how tourists with specific access requirements can be suitably catered for within the overall framework of sustainable cultural tourism destination management.

\section{CONTRIBUTION}

This paper, reporting on the work-in progress of the IMPACTOUR project, reviews a number of key sources and describes how information tools can support CT destinations in managing the demands of the growing accessible tourism market and fulfilling the human rights approach of the UNCRPD. The needs of visitors with disabilities or with specific access requirements are generally insufficiently addressed in the system of indicators concerning accessibility information, access provisions and performance, visitor satisfaction and, therefore, the economic impacts/value-added of these target groups is not clearly defined.

We believe that the Cultural Tourism sector should have the opportunity to benefit from the accessible tourism market and give all tourists the opportunity to visit, learn and appreciate the cultural heritage of Europe in all its richness and variety. With the IMPACTOUR project and the planned data-driven management tool, we hope to ensure that CT destinations can provide inclusive and accessible experience for both local citizens, who are a mainstay of many cultural venues and events, and for visitors, both from the region and from afar.

The lack of data on destinations' accessibility may be regarded as a significant "gap" in relation to accessibility planning, affecting policy formulation, performance monitoring, and impact measurement. With better criteria and indicators, destinations can be offered more appropriate tools for holistic destination management.

\section{RECOMMENDATIONS}

The following initial recommendations are developed for the IMPACTOUR project regarding indicators for assessing and managing the accessibility of CT destinations:

- The importance of inclusion and accessibility measures as components of sustainable development responding to the diversity of visitors and the ageing population of Europe

- The need to introduce the practice of using Accessibility Information Schemes (AIS) in cultural tourism destination management and marketing.

- The need to support DMO managers through awareness-raising and training in accessibility and customer service, leading to a cultural shift towards accessible and inclusive service design and marketing to a wider diversity of visitors

- The need for accessibility to be embedded across the social, cultural, environmental and management areas of a destination's tourism, cultural and heritage resources

- The recognition of accessibility as a supporting factor in sustainability in the environmental, social and economic domains. 
ToSEE - Tourism in Southern and Eastern Europe, Vol. 6, pp. 25-37, 2021.

I. Ambrose, K. Papamichail: INFORMATION TOOLS FOR CULTURAL TOURISM DESTINATIONS...

The need to incorporate visitor-generated data (feedback, surveys) as a component of the demand-side indicator framework an as a tool for continuous improvement of CT offers.

\section{ACKNOWLEDGEMENTS}

This article was prepared in connection with the European Union Horizon 2020 funded project, IMPACTOUR on "Improving Sustainable Development Policies and Practices to access, diversify and foster Cultural Tourism in European regions and areas", grant agreement ID: 870747. The authors wish to acknowledge the contributions of the project partners to the development of this article.

\section{REFERENCES}

Ambrose, I. (2021), “Accessible Tourism”, in Buhalis, D. (Ed.), Encyclopedia of Tourism Management and Marketing, Edward Elgar Publishing.

Buhalis, D., Michopoulou, E., (2011), "Information-Enabled Tourism Destination Marketing: Addressing the Accessibility Market", Current Issues in Tourism, Vol. 14, No. 2, pp. 145-168. https://doi.org/10.1080/13683501003653361

Buhalis, D, and Michopoulou, E., (2013), "Information Provision for Challenging markets: the Case of the Accessibility Requiring Market in the Context of Tourism”, Information \& Management, Vol 50 , pp. 229-239. https://doi.org/10.1016/j.im.2013.04.001

Buhalis, D. and Darcy, S. (eds), (2011), Accessible tourism: Concepts and issues, Channel View Publications, Bristol.

Buhalis, D., Darcy, S. and Ambrose, I. (eds), (2012), Best Practices in Accessible tourism, Channel View Publications, Bristol.

European Commission (2014), EU Study: Mapping the Skills and Training Needs to Improve Accessibility in Tourism Services. VVA, 3S and ENAT, DG Enterprise, Tourism Unit, Brussels.

European Commission (2015), EU Study: Mapping the Supply and Performance of Accessible Tourism Services in Europe, Report by VVA, ENAT and EWORX S.A., DG Enterprise, Tourism Unit, Brussels.

European Commission (2016), ETIS, the European Tourism Indicators System for sustainable tourism, DG Enterprise, Tourism Unit, Brussels.

European Commission (2021), Cultural Tourism. DG Enterprise, Tourism Unit, Brussels, viewed 19 May 2021, https://ec.europa.eu/growth/sectors/tourism/offer/cultural_en

EU Commission (2019), Study on the feasibility of a European tourism indicator system for sustainable management at destination level (2019), DG Enterprise, Tourism Unit, Brussels.

Global Sustainable Tourism Council (GSTC), Destination Criteria (Version 2.06 December 2019), viewed 19 May 2021, https://www.gstcouncil.org/gstc-criteria/gstc-destination-criteria/

International Standards Organisation (ISO), ISO 201902:2021, Tourism and related services — Accessible tourism for all - Requirements and recommendations, ISO, Geneva.

Michopoulou, E., Darcy, S., Ambrose, I. and Buhalis, D. (2015), "Accessible tourism futures: the world we dream to live in and the opportunities we hope to have", Journal of Tourism Futures, Vol. 1, No. 3, pp. 179-188. https://doi.org/10.1108/JTF-08-2015-0043

UN General Assembly, Convention on the Rights of Persons with Disabilities, 13 December 2006, A/RES/61/106, viewed 19 May 2021, https://www.refworld.org/docid/4680cd212.html

UN General Assembly, Transforming our world: the 2030 Agenda for Sustainable Development, 21 October 2015, A/RES/70/1, viewed 19 May 2021, https://www.refworld.org/docid/57b6e3e44.html

Veitch, C.G. (2017), Accessible Tourism: A Competitive Opportunity for Destinations \& Businesses. Simple View, viewed 19 May 2021, https://www.simplevieweurope.com/blog/read/2017/07/accessibletourism-a-competitive-opportunity-for-destinations-and-businesses-b94

World Tourism Organization (1999), Global Code of Ethics in Tourism, viewed 19 May 2021, https://www.unwto.org/global-code-of-ethics-for-tourism

World Tourism Organization (2013), Recommendations on Tourism for All. UNWTO General Assembly Resolution A/RES/637(XX) of August 2013, viewed on 19 May 2021. https://www.e-unwto.org/doi/book/10.18111/9789284415984 
ToSEE - Tourism in Southern and Eastern Europe, Vol. 6, pp. 25-37, 2021

I. Ambrose, K. Papamichail: INFORMATION TOOLS FOR CULTURAL TOURISM DESTINATIONS...

World Tourism Organization (2015), Manual on Accessible Tourism. Module IV: Indicators for Assessing Accessibility in Tourism (Español), viewed on 19 May 2021,

https://webunwto.s3-eu-west-1.amazonaws.com/2019-08/150616turaccsmodulo4webacc.pdf

World Tourism Organization (2019), Kyoto Declaration on Tourism and Culture: Investing in future generations, UNWTO Declarations, Vol. 28, No. 4, UNWTO, Madrid, https://doi.org/10.18111/unwtodeclarations.2019.28.04

World Tourism Organization (2020) Inclusive Recovery Guide - Sociocultural Impacts of COVID-19, Issue I: Persons with Disabilities, https://doi.org/10.18111/9789284422296

Ivor Ambrose, (Mr.) Managing Director,

European Network for Accessible Tourism (ENAT) a.s.b.l.,

Rue du Commerce 72, 1040 Brussels, Belgium

+306944433646

enat@accessibletourism.org

Katerina Papamichail, (Ms.) Architect,

European Network for Accessible Tourism (ENAT) a.s.b.l.,

Rue du Commerce 72, 1040 Brussels, Belgium

+306944433646

enat@accessibletourism.org 